\title{
Romantizmle postmodernizm arasındaki bağlantılara dair bir açımlama
}

\section{Funda KIZILER EMER ${ }^{1}$}

\begin{abstract}
APA: Kızler Emer, F. (2020). Romantizmle postmodernizm arasındaki bağlantılara dair bir açımlama. RumeliDE Dil ve Edebiyat Araştırmaları Dergisi, (20), 326-337. DOI: 10.2900o/rumelide.791682.
\end{abstract}

\section{$\ddot{\mathbf{O} z}$}

$\mathrm{Bu}$ çalışma kapsamında romantizm ve postmodernizm kavramlarının genel bir tanımı yapılarak her ikisi arasındaki düşünsel ve sanatsal bağlantılar aydınlatılmaya çalışılmıştır. Bu bağlamda çalışma, karşılaştırmalı bir kavram analizi niteliği taşımaktadır. Düşünsel açıdan her iki kavram da öncelikli olarak Aydınlanmacı modernite eleştirisiyle ırasallaşır. Yazına mutlak anlamda özgürlük tanımaları, sanatla yaşam arasındaki keskin sınırları muğlaklaştırma girişimleri bakımından da sanata bakışları dikkat çekici ölçüde birbirleriyle örtüşür. 1790'ların ikinci yarısında Almanya'da doğan Romantik yazın akımı, 180o'lü yılların başında tüm Kıta Avrupa'sını etkisi altına alarak yaklaşık kırk yıllık uzun bir sürece hâkim olur. Özgürlükçü ve anarşist tutumuyla öne çıkan Romantik akım, 1789 Fransız Devrimi'nin yarattığı özgürlük ve demokrasi ruhunun yazın ve sanat alanına yansıması olarak okunabilir. Fantezi/ düş, duygu, sonsuzluk özlemi ve şiir anahtar kavramlarıyla ırasallaşan Romantizm, modernizmin düşünsel temellerini oluşturan Aydınlanma'nın katı ve indirgemeci usçuluğuna (rasyonalizm) bir tepki niteliği taşır. Postmodernizmse, Aydınlıklar Avrupası'nın "Heil! Heil!-Duçe! Duçe!” haykırışlarıyla devasa kitleleler halinde karanlıklara koştuğu II. Dünya Savaşı sonrasında uyanan yeni bir tinsel bilinci, modernizmin temellerini kökten biçimde sorunsallaştıran bir özdüşünümsellik sürecini ifade eder. Romantizmden iki yüzyl kadar sonra ortaya çıan postmodernizm, Romantiklerin başlattığı modernite eleştirisini her anlamda en uç noktasına taşımış ve onların yazını yaşamla bütünleştirerek her tür sınırlandırma ve sınıflandırmadan özgürleştirme istemini bizzat kılgıya geçirmişlerdir. Bu bağlamda postmodernizmin post-romantik olduğu savlanabilir ki, bu çalışmanın temel amacı; postmodernizmin romantizmle arasındaki bu derin bağlantıları açığa çıkarmaktır.

Anahtar kelimeler: Romantizm, postmodernizm, karşılaştırma, kavram, analiz

\section{An exposition of the relationship of the romanticism to the postmodernism}

\begin{abstract}
Within the scope of this study, a general definition of the concepts of postmodernism and romanticism was made and the intellectual and artistic connections between both were tried to be illuminated. In this context, the study is a comparative concept analysis. From an intellectual perspective, both concepts are inherited primarily with the critique of Enlightenment modernity. Their views on art coincide remarkably with each other in terms of their absolute freedom to writing and their attempts to blur the sharp boundaries between art and life. Romantic literature born in Germany in the second half of the 1790s, dominated the entire continental Europe in the early 180os, dominating a long period of about forty years. The Romantic movement, which stands out with its libertarian and anarchist attitude, can be read as the reflection of the spirit of freedom and democracy
\end{abstract}

Doç. Dr., Sakarya Üniversitesi Fen-Edebiyat Fakültesi, Alman Dili ve Edebiyatı Bölümü (Sakarya, Türkiye), fkiziler@sakarya.edu.tr, ORCiD ID: oooo-0003-2204-3063 [Makale kayıt tarihi: 25.08.2020-kabul tarihi: 20.09.2020; DOI: $10.29000 /$ rumelide.791682] 
created by the French Revolution of 1789 in the field of literature and art. Romanticism, which is rationalized with the key concepts of fantasy / dream, feeling, longing for eternity and poetry, is a reaction to the rigid and reductionist rationality (rationalism) of the Enlightenment, which constitutes the intellectual foundations of modernism. Postmodernism expresses a new spiritual consciousness awakened after World War II and a process of self-reflexivity that radically problematizes the foundations of modernism, where Europe in the Enlightenment period ran into the darkness in huge masses with its cries of "Heil! Heil! - Duce! Duce!". Postmodernism, which emerged two centuries after Romanticism, brought the criticism of modernity initiated by the Romantics to its extreme point in every sense, and by integrating their writing with life, they personally put into practice the desire to liberate from all sorts of restrictions and classifications. In this context, it can be claimed that postmodernism is post-romantic. The main purpose of this study is to reveal these deep connections between postmodernism and romanticism.

Keywords: Romanticism, postmodernism, comparison, concept, analysis

\section{Giriş}

$\mathrm{Bu}$ çalışmanın temel çıkış noktası; romantizm ve postmodernizm arasında düşünsel ve yazınsal programları açısından incelenmeye değer bir ortaklık olduğu savıdır ve temel amacı da, postmodernizmin romantizmle arasındaki bu bağlantıları açığa çıkarmaktır.

Karşılaştırmalı bir kavram analizi niteliği taşıyan bu çalışma kabaca iki ana aşamadan oluşmaktadır: İlk aşamada romantizm ve postmodernizm kavramları; etimolojisi, tanımı, kısa tarihçesi ve temel ilkeleri vb. açlardan genel hatlarıyla değerlendirilerek okura tanıtılmıştır. Sonraki aşamada her iki kavramın birbirleriyle örtüşen/ yakınlaşan noktaları saptanmış ve aralarındaki söz konusu bağlantıların karşılaştırmalı olarak analiz edilmiştir.

Romantizm 18. Yüzyll sonunda, tarihsel açıdan 1789 Fransız Devrimi ve Napolyon Savaşlarının (17951815) belirleyici bir rol oynadığı bir dönemde, postmodernizmse yıkımları tüm dünyayı etkileyen II. Dünya Savaşı (1939-1945) sonrası dönemde, 20. Yüzyılın ikinci yarısında ortaya çımıştır. Farklı zaman dilimlerinde ortaya çıkan her iki kavram da düşünsel açıdan herşeyden önce 18. yüzyılın Aydınlanma dünyasında doğduğu kabul edilen moderniteye yönelik eleştirel tutumlarıyla ırasallaşır. Ayrıca her iki kavram, yazına/ sanata bakışları ve mutlak anlamda özgürlük tanımaları, sanatla yaşam arasındaki keskin sınırları belirsizleştirme girişimleri bakımından da dikkat çekici ölçüde birbirleriyle örtüşmektedir, hatta öyle ki, romantizmle örtüşen bu noktalar göz önüne alındığında, postmodernizm 'post-romantik' diye nitelendirilebilir.

Bu makalede özellikle bu iki saptama doğrultusunda postmodernistlerin kendilerinden yaklaşı iki yüzyll kadar önce romantiklerin başlattığı modernite eleştirisini her anlamda en uç noktasına taşıyıp onların yazını yaşamla bütünleştirme, her tür sınırlandırma ve sınıflandırmadan özgürleştirme istemini bizzat kılgıya geçirdiğinin gösterilmesi hedeflenmiştir.

\section{Romantizm ve postmodernizm kavramlarına genel bakış}

"Romantik" ve "roman" kavramları, aynı kökenden gelip etimolojisi Eski Fransızca "romanz" sözcügüne dayanır. "Romanz" aydınların kullandığı Latince'ye karşıt olarak Roman "halk dillerinde" ("lingua romana"); yani Fransızca, İspanyolca, Portekizce, İtalyanca ve Rumence dillerinde yazılmış anlamına gelir (Kaiser, 2010, s. 9). 18. Yüzyıl sonlarında yeni bir sanat, yaşam ve dünya anlayışı olarak Almanya'da 
ortaya çıkıp kısa sürede Fransa, İtalya ve İngiltere'ye yayılan Romantik akım, ${ }^{2}$ Avrupa yazını, sanatı ve kültürü üzerinde 19. Yüzyılın ilk çeyreğine dek etkisini sürdürmüştür. Romantizmin doğum tarihi ve yeri 1790'lar Almanyası3 olarak gösterilir (Wilpert, 1989, s. 793). "Düşün tarihsel açıdan Alman İdealizminin son evresi(ne)" karşılık gelen Romantizm, kendisinden önce gelen "Deha Çağı (Sturm und Drang) ve Klassisizm akımlarının yüksek bir bileşkesi, ussal ve usdışı güçlerin bir sentezi olarak"4 okunabilir (Frenzel, 1987, s. 296).

Wilhelm H. Wackenroder'le (1773-1798) Ludwig Tieck'in (1773-1853) Herzensergießungen eines kunstliebenden Klosterbruders (1796) adlı on sekiz ayrı metinden oluşan yapıtı (Wackenroder/ Tieck 2009, s. 5-116) 'romantizmin manifestosu' olarak kabul edilir. Romantizmin ilkeleri dizgesel olarak olmasa da, ilk kez bu yapıtta ifade edilmiştir ki, bunlar; katı usçuluğa karşı duygunun ve maneviyatın büyük önem kazanması, nesnellik yerine öznelliğin ön plana çıkması, Aydınlanmanın ussal ve dindışı dünya tasarımına karşıt olarak orta çağın Tanrı tarafından yaratılmış bütüncül dünya anlayışına yönelim, sanatın kutsallığına, yaşamın ve doğanın gizemlerine ve insanın ruhsal, dinsel ve aşkın boyutuna ve özellikle de Katolisizme yapılan vurgu şeklinde özetlenebilir (Kaiser, 2010, s. 10-15). Bu manifestonun ortaya koyduğu gibi, aslında romantizm kendi kimliğini Aydınlanmacı modernizmin eleştirisi üzerine inşa eder. Nitekim Octavio Paz'ın (1914-1998) belirttiği gibi romantizm; herşeyden önce yönetimin, siyasetin, geçmişin, inancın, örf, adet ve geleneklerin, cinsellik dahil yaşamın her alanının eleştirisi anlamına gelen modernizmin, yani bizzat "Eleştiri Çă̆g'nın çocuğu(dur)." Ancak bu, ona başkaldıran, "(a)si bir çocuk(tur)"; Aydınlanmacı "modernitenin büyük olumsuzlaması()", hatta bu bağlamda "ussal eleştirinin bir eleştirisi(dir)” (1990, s. 39).

Romantizm, özellikle Klassisizmde zirveye vardığı gibi o zamana kadar yazın dünyasına egemen olan Antikite'ye yönelim yerine, bizzat kendi halkının tarihine, kendi halkının diline, sanatına, efsane, masal ve mitlerine yönelimle ırasallaşır. Romantiklerin ulusal değerlere ve geçmişe yöneliminin 5 arka planında dönemin tarihsel gerçekliklerinin önemli bir payı vardır ki, bunların başında Napolyon Savaşları (17951815) gelir. Bilindiği üzere 1804'te Napolyon Bonapart'ın (1769-1821) kendini imparator ilan etmesiyle Kutsal Roma-Germen İmparatorluğu resmen sonlanmış, iki yıl sonra da Almanya, Napolyon ordularının işgaline (1806) uğramıştır. Alman prenslerinin Napolyon'la ittifak kurmasına karşı çıkan romantiklerin birçoğu Kurtuluş Savaşları'na (1813-1815) destek vermiş ya da bizzat katılıp savaşmıştır (Ünal, 2011, s. 97-98); (Schultz, 2006, s. 87-92). Romantizmin tarihsel arka bahçesinde parçalanmış, dağılmış, işgal altındaki bir Almanya (Prusya) söz konusu olduğu için, birlik ve bütünlüğe özlem duygusu ve ulusçuluk başat konumdadır.

2 Romantizmin farklı Avrupa ülkelerindeki açılımlarına dair Kefeli şunlara dikkat çekiyor: "Batı'da yaşanan bunalımlar, iç savaşlar ve devrimler aynı anda başlamamış, aynı şekilde gelişmemiştir. Her ülke benzer olaylar karşısında kendi milli kimliği, kendi siyasi, tarihi koşulları ve kendi hedefleri doğrultusunda bu olaylara tepki gösterir. [...] Farklılıkları itibarıyla ele alındığında romantizm İngiltere'de estetik bir hareket, Fransa'da Rousseau'dan kaynağını alan toplumsal eleştiri, Almanya'da ise estetik bir hareket olarak doğan, zaman içinde bir dünya görüşü haline gelen bir akımdır" (2014, s. 6263).

3 Romantizm, 1795 yllında Almanya/ Jena'da bir araya gelen ve kendilerine "Romantik" diyen bir grup kadın ve erkek yazar tarafından kurulmuştur (Vogelpohl, 2005, s. 107). Jena'da toplanan bu öncü romantikler; Schlegel Kardeşler ve eşleri, Novalis, Tieck, ayrıca Schelling ve Schleiermacher'dir (Rothmann, 2003, s. 136). Romantizm; Erken Dönem/ Jena Romantizmi (Frühe/ ältere/ Jenaer Romantik, 1798-1804), Heidelberg Romantizmi (Heidelberger Romantik, 1804-1818) ve Geç Dönem/ Berlin Romantizmi (Späte/ jüngere/ Berliner Romantik, 1818-1835) şeklinde üç evreye ayrllır (Frenzel, 1987, s. 296 vd.); (Ünal, 2011, s. 95).

4 Tarafimdan Türkçeye çevrilmiştir. sergiler. Taşdelen bunu şöyle açımlıyor: "Eski zamanlar ve yeni zamanlar", "antik ve modern” ayrımının da ortaya koyduğu gibi, modern, her zaman yeni olanla, şimdi olanla, çağdaş olana kendini ifade eder. Bununla birlikte eski ve yeni arasındaki ayrım, yalnızca zamansal bir ayrım olmayıp bir felsefeyi, bir dünya görüşünü, bir tavrı da ifade eder. Öyle ki, başka bir felsefe ve dünya görüşü karşısında yadsıyıcı, yargılayıcı ve ötekileştirici bir tavra büründü̆̆̈ bile söylenebilir” (2007, s. 50). 
Postmodernizm kavramına gelince; Latince "post" öneki "sonra" anlamına gelmektedir. O halde bu önekin, - yine Latince "modo"dan türetilen ve "tam şimdi”yi imleyen - "modern” sözcügüüle bileşimi olan "postmodern”, 'modern sonrası'nı ifade eder. İlk kez 1870'lerde İngiliz sanatçı John Whatkins Chapman (1853-1903) tarafindan, Fransa'da doğan izlenimci (empresyonist) resim sanatından daha modern olan resimleri betimlemek için kullanılmıştır. Kuzey Amerika doğumlu olup yazın ve sanat alanlarında (Sontag, Hassan, Fiedler vb. yazarlar tarafından) yapılan tartışmalarla yaygınlaşan moda kavram, daha sonra Avrupa'ya, Fransa'ya taşınarak, (Lyotard, Foucault, Derrida, Barthes, Baudrillard vb.) Fransız düşünürler tarafından geliştirilmiştir (Şaylan, 1999, s. 22-39). Postmodernizm sözcügü̈; modernizmden sonrasi; modernizmin tersi; ileri/ geç anamalcılı (kapitalizm); sanatta melezlik ve seçmecilik (eklektisizm); küreselleşme (globalleşme) gibi birçok farklı anlamda kullanılmaktadır (Birkök, 1998, s. 526).

1960'ların sanat ve yazın dünyasında ortaya çıkan bu kavram, üretimsel, bilimsel, düşünsel, toplumsal, siyasal, kültürel vb. açılımları olan "çokkatlı bir dönüşüm sürecini imler" (Welsch, 2002, s. 11). "Postmodern durum"un ${ }^{6}$ hazırlayıcısı, 1945 sonrasında dünya çapında yaygınlık kazandığı gözlenen "bilimsel ve teknolojik"; "ekonomik ve ekinsel”; "siyasal ve felsefel dönüşüm” şeklinde özetlenebilecek olan üç yönlü bir dönüşüm olgusudur (Kızller, 2006, s. 120-124). Ancak tarihsel bir dönemselleştirmeden çok düşünsel/ zihinsel bir dönüşümü imleyen "postmodern" (Lyotard, 1986-1987, s. 209), herşeyden önce modernlik üzerine kökten bir özdüşünümsellik sürecine karşlılı gelir. Postmodern, aslında "modernliğin içinde yatan düşünümselliğin daha kapsamlı olarak" (Giddens, 1998, s. 51), en radikal biçimde açığa çıkması olarak okunabilir.

II. Dünya Savaşı (1939-1945) postmodernizmin doğumunda anahtar konumdadır. Fransız düşünür Jean F. Lyotard'ın (1924-1998) açıladığı gibi, II. Dünya Savaşı'ndaki büyük insanlık suçunu somutlaştıran Auschwitz toplama kampı paradigmasından sonra, modernitenin insanlı̆̆ın yücelmesi yolunda teleolojik ilerleme düşü, özgür bireyler, gönenç toplumları ya da sinıfsız toplumlar yaratma vb. ülküleri, daha doğrusu Aydınlanma, Marksizm, İdealizm gibi "büyük anlatılar"ı ("metanarrative") inanılırlı̆̆ını tümüyle yitirmiştir (Lyotard, 1998, s. 20) ki bu, "büyükanlatıların” ölümü anlamına gelmektedir (Lyotard, 1984, s. 15). "Büyükanlatıların” ölümünün ilan edilmesi; "ortada tek bir us değil çeşitli uslar olmasından ötürü artık bütünleştirici bir us düşüncesi(nin)” (Sarup, 1997, s. 190) iptali, daha açık bir söylemle Avrupa ve Hıristiyan merkezciliğin sona ermesi anlamına gelir. Bu ölüm bildirisinin ardından da peş peşe öznenin (Derrida/ Foucault), insanın (Foucault), metafiziğin ve temsilin (Derrida/Foucault), ideoloji ve ütopyanın (Bell) ve tarihin (Fukuyama) ölümü bildirileri gelmiştir (Kızler, 2006, s. 127-138); (Emer Kızller, 2019, s. 228). Tüm bu ölüm bildirileri postmodernizmin, modernizmin temellerini kökünden sarsarak, onu ne kadar ‘ölümcül' biçimde eleştirdiğinin açık birer göstergesidir.

\section{Romantizm ve postmodernizm kavramları arasındaki düşünsel bağlantılar}

Özgürlükçü ve anarşist tutumuyla öne çıkan Romantik akım, 1789 Fransız Devrimi’nin yarattı̆̆ devrim, özgürlük ve demokrasi ruhunun yazın ve sanat alanına yansıması, modernizme yönelik ilk önemli başkaldırı olarak okunabilir. Us yerine duyguya, fizik yerine metafiziğe; kural yerine kuralsızlı̆̆a, düzen yerine anarşiye, maceraya, doğaya, bilinmezliğe, mucize ve gizeme, düş ve hayallere, din ve inanca, aşk ve şiire yönelen romantizm, "sanat ve edebiyat alanında başkaldırııı, ölçüsüzlüğü, düzensizliği ifade

\footnotetext{
$6 \quad$ Aynı adlı kült kitabın yazarı olan Jean F. Lyotard’a göre 1945 sonrasındaki bilimsel ve teknolojik gelişmeler tüm dünyada "bilgisayarlaştırılmış toplumlar" (1984, s. 3) yaratmıştır.
} 
ede(r)"7 (Bumin, 2002, s. 194). "Mavi çiçek" (“die blaue Blume”)8 motifinin somutlaştırdığı sonsuzluk özlemiyle ırasallaşan romantizm, modernizmin düşünsel temellerini oluşturan Aydınlanma'nın katı ve indirgemeci usçuluğuna (rasyonalizm) bir tepki niteliği taşır.

“Romantikler Aydınlanmanın sert muhalifleriydiler" diyen Vogelpohl'un söylemiyle onlar öncelikle "Aydınlanmanın heyecansız kuru düşünme tarzını reddettiler; [...]; genellikle duygusal kişilerdi ve tercih edebilselerdi gerçek yaşamı masala dönüştüreceklerdi” (2005, s. 107). Yaşamın düşten, hayalden, gizemden, mistisizmden ve şiirden uzaklaştırılmasından, aydın kesimle halk arasındaki ve dolayısıyla bunların yazınsal üretimleri arasındaki kopukluktan kaygı duyan romantikler, bundan Aydınlanma'yı sorumlu tutarlar (Frenzel, 1987, s. 297). Hermann A. Korffa (1882-1963) göre, Romantizm ve Aydınlanma arasında büyük bir karşıtlık söz konusudur. Arthur Henkel (1915-2005) de benzer şekilde romantizmi "temelleri Descartes'a dayanan modern ben-felsefesinin krizi"9 (Henkel'den akt. Frenzel, 1987, s. 296) olarak nitelendirir.

“(H)erşeyden önce modern sanatın ve estetik anlayışının öncüllerinin radikal bir biçimde yadsınması anlamına" (Şaylan, 1999, s. 47-48) gelen romantizmden yaklaşık iki yüzyll sonra ortaya çıkan postmodernizmin, onun modernizme yönelttiği başkaldırıyı devraldı̆̆ı savlanabilir. Şöyle ki:

\begin{abstract}
"Sontag edebiyatta yeni/farklı bir duyarlı gereksiniminden söz ediyordur. Fiedler ise sanatsal/seçkinci edebiyat ile eğlencelik edebiyat arasındaki aşılmaz hendeğin doldurulması, edebiyatın yaşamla bütünleşmesi ve sıradan okurun beklentilerinin doyurulması gerekliliğini dile getiriyordur. Altmışlı ylların kalıplaşmış ölçütleri karşısına alan, alternatif arayışlarla bütünleşmiş̧ atmosferin içinde, edebiyat alanından gelen bir başkaldırıdır bu. Söz konusu başkaldırının hedefleri arasında; geleneksel/ yansıtmacı sanat anlayışı, sosyal/ kültürel modernizmin mutlak doğruları/ söylemleri/efsaneleri ve estetik modernistlerin seçkinci ciddiyeti ilk sırada yer almaktadır" (Ecevit, 2004, s. 67).
\end{abstract}

Ancak bu başkaldırı, modernizmin ortaya koyduğu "yerleşik ölçütlerin kendileri değil, bu ölçütlerin alternatifsiz doğrular olarak görülmeleridir." Çünkü "postmodern düşünce kaynağını çoğulculuktan alır; onda tek ve mutlak olana yer yoktur" (s. 68). Postmodernizmin en belirgin rasalı olan "çoğulculuk" kavramına gelmişken, bu unsurun aynı zamanda romantizmle arasındaki en büyük farkı oluşturduğuna dikkat çekmek gerekir: Tarihsel art alanlarını ele alırken gösterildiği gibi, romantizmin parçalanmış bir dünyada birlik ve bütünlüğe yönelik derin bir özlemi varken, postmodernizm "kökten çoğulculuk" 10 (Welsch, 2002, s. 4) tasarımıyla bütün yerine (dilsel, dinsel, etnik kültürel, düşünsel, yaşamsal, cinsel, vb. her anlamda) farklılı̆̆ı ve çeşitliği kucaklar.

Düşüntarihsel açıdan postmodernizm herşeyden önce, Aydınlıklar Avrupası'nın "Heil! Heil!- Duçe! Duçe!” haykırışlarıyla devasa kitleleler halinde karanlıklara koştuğu II. Dünya Savaşı sonrasında uyanan yeni bir tinsel bilinci imler. Kendini her şeyin üstünde bir tür üst/ evrensel akıl olarak konumlandıran Aydınlanmacı modernizmin, endüstriyel-bilimsel-teknolojik -"sapandan megaton bombasına doğru" (Adorno, 2016, s. 290) - ilerlemeyle birey olarak insanı aydınlatma, her tür boyunduruktan özgürleştirme ve yüceltme projesinin, ${ }^{11}$ dünyanın bu ikinci büyük savaşında uygulanan sistematik

2002'de Prof. Dr. Tülin Bumin yönetmenliğinde toplanan uzman bir ekibinin şu kaynaktan yaptığ çevirilerden oluşmaktadır: Cours de Philosophie, Compléments pour Terminales L et ES d.André Vergez et Denis Huisman; Editions Nathan 1998

$8 \quad$ Friedrich F. von Hardenberg’in (Novalis) Heinrich von Ofterdingen adlı yapıtında geçen bu motif, zamanla dünya çapında romantizmin temel simgesi haline gelmiştir. (Novalis 1975: 74-75).

Tarafımdan Türkçeye çevrilmiştir.

Tarafımdan Türkçeye çevrilmiştir.

"İnsanlığın gelişmesi ve ilerlemesi projesi, aklın oluşturduğu aydınlık yok olunca, iki savaş ile kararınca, insan, yalnız modernizmin söylemlerine karşı değil, kendine ve Tanrı “ya karşı duymuş olduğu güveni de yitirmiştir” (Taşdelen, 2007, s. 63). 
soykırım gerçeği ve Hiroşima ve Nagasaki'ye atılan atom bombaları karşısında karaya vurduğu gerçeğiyle yüzleşip hesaplaşan Batının, modernizmin temellerini kökten biçimde sorunsallaştıran - art arada gelen ölüm bildirilerinin de berkittiği gibi - bir özdüşünümsellik sürecine girişini ifade eder ki, işte bu nokta, postmodernizmin romantizmle arasındaki en önemli bağlantı noktası olarak karşımıza çlkar.

Görüldüğü gibi, her iki kavramın da modernizmle arasında eytişimsel bir ilişki söz konusudur; her ikisi de modernizmle aralarındaki göbek bağına karşın, ona karşı kökten bir eleştirel bakış açısı geliştirmeleri bakımından birbirleriyle dikkat çekici ölçüde örtüşmektedir.

\title{
Romantizm ve postmodernizmin yazına ve sanata bakışı
}

Romantizm ve postmodernizmin Aydınlanmacı modernite eleştirisinde buluşan düşünsel bağlantılarının yanı sıra, genel anlamda yazına ve sanata bakışları, sanatla diğer disiplinler ve bizatihi yaşam arasındaki ilişkileri açığa çıkarma, sanatla yaşam arasındaki keskin sınırları belirsizleştirme, yazını her tür sınıflandırma ve sınırlandırmadan mutlak anlamda özgürleştirme girişimleri bakımından da birbirleriyle benzerlikler arz ettiği gözlenmektedir.

Çalışmada öne sürülen bu hipotezi belgitlemek için kullanılan temel argüman şudur: Erken Dönem Alman Romantizmin en önemli yazar ve kuramcllarından olan Friedrich Wilhelm Schlegel'in (17751854) "evrensel şiir" ("Universalpoesie") (2005, s. 90-91) tasarımıla, "Novalis" takma adlı Friedrich Freiherr von Hardenberg’in (1772-1801) dünyayı "romantikleştirme" ("Romantisiren”) (1975, s. 493) işlemi; kanonik/ hiyerarşik/ seçkinci modernist yazının getirdiği yazınsal ölçüt ve kategorileri yapıbozumuna uğratarak temellerinden sarsan 'anarşist ruhlu' postmodern yazınla romantizm arasındaki bağlantıları ortaya koymaktadır.

Friedrich Schlegel ünlü Athenäum-Fragmanları'nın (1798) (2005, s. 76-143) 116.’sında şöyle yazar:

\begin{abstract}
"Die romantische Poesie ist eine progressive Universalpoesie. Ihre Bestimmung ist nicht bloß, alle getrennten Gattungen der Poesie wieder zu vereinigen und die Poesie mit der Philosophie und Rhetorik in Berührung zu setzen. Sie will und soll auch Poesie und Prosa, Genialität und Kritik, Kunstpoesie und Naturpoesie bald mischen, bald verschmelzen, die Poesie lebendig und gesellig und das Leben und die Gesellschaft poetisch machen, den Witz poetisieren und die Formen der Kunst mit gediegnem Bildungsstoff jeder Art anfüllen und sättigen und durch die Schwingungen des Humors beseelen. Sie umfaßt alles, was nur poetisch ist, vom größten wieder mehrere Systeme in sich enthaltenden Systeme der Kunst bis zu dem Seufzer, dem Kuß, den das dichtende Kind aushaucht in kunstlosem Gesang [...] Die romantische Dichtart ist noch im Werden; ja das ist ihr eigentliches Wesen, daß sie ewig nur werden, nie vollendet sein kann. Sie kann durch keine Theorie erschöpft werden [...]. Sie allein ist unendlich, wie sie allein frei ist und das als ihr erstes Gesetz anerkennt, daß die Willkür des Dichters kein Gesetz über sich leide. Die romantische Dichtart ist die einzige, die mehr als Art und gleichsam die Dichtkunst selber ist: denn in einem gewissen Sinn ist oder soll alle Poesie romantisch sein" (2005, s. 90-91).
\end{abstract}

Schlegel burada öncelikle, Aristoteles’ten beri epik, lirik, drama diye birbirinden ayrlan yazınsal türler arasındaki sınırları muğlaklaştırıp bozmayı, sonra bunları "yeniden birleştirme(yi)" hedefleyen bir yazın tasarımı ortaya koyar. Bu tasarıma göre yazın; daimî bir "oluş içinde" (“im Werden”) açınmakta olan ("progressiv"), "hiçbir zaman tamamlanmamış", “özgür” ve "sonsuz” bir nitelik taşır, öyle ki; "(h)içbir kuram tarafından tüketilemez". O halde romantizmin bakış açısından yazın ya da her daim oluş halindeki "oluşumsal evrensel şiir" ("progressive Universalpoesie”), dinamik ve devinimsel doğasından dolayı sınıflandırılıp sinırlandırılamaz, kalıplandırılıp kuramsallaştırılamaz. Schlegel’in ortaya attığı bu yazın tasarımı; "şiiri felsefe ve retorikle ilişkilendi(rerek)", sanatla diğer disiplinler ve hatta bizatihi 
sanatla yaşam arasında önceden belirlenmiş sınırları bozup iç içe geçiren, bunlar arasındaki örgensel bağlara dikkat çeken "şiiri canlı ve toplumsal, yaşamı ve toplumu da poetik kılmayı" ${ }^{12}$ düşleyen bir yazın ve yaşam tasarımı olarak romantizmin şahdamarı konumundadır. Kaiser bu nedenle, Schlegel'in "Universalpoesie" kavramındaki "evrensel” sözcügünün, "sınırları aşan" ["grenzüberschreitend"] anlamına geldiğini belirtir (2010, s. 24). Rothmann'a göre "Universalpoesie", sonsuz'la ilgilenen; sonlu insanın arzularının, düş ve özlemlerinin sonsuzluğuna yönelen bir kavram olarak "inanç ve bilim, bilim ve sanat, sanat ve din arasındaki sınırları aşar. Tüm sanatların birbiriyle karşılıklı ilişki içinde olduğunu vurgular $[\ldots]{ }^{13}$ (2003, s. 137).

Romantizmin bir diğer öncüsü olan Novalis de Schlegel'in ortaya attı̆̆ı bu yazın tasarımını berkiten "romantikleştirme" operasyonunu şöyle açımlar:

\begin{abstract}
"Die Welt muß romantisirt werden. So findet man den urspr[ünglichen] Sinn wieder. Romantisiren ist nichts, als eine qualit[ative] Potenzirung. Das niedre Selbst wird mit einem bessern Selbst in dieser Operation identificirt. So wie wir selbst eine solche qualit[ative] Potenzenreihe sind. Diese Operation ist noch ganz unbekannt. Indem ich Gemeinen einen hohen Sinn, dem Gewöhnlichen ein geheimnißvolles Ansehn, dem Bekannten die Würde des Unbekannten, dem Endlichen einen unendlichen Schein gebe so romantisire ich es - Umgekehrt ist die Operation für das Höhere, Unbekannte, Mystische, Unendliche - dies wird durch diese Verknüpfung logarythmisirt - Es bekommt einen geläufigen Ausdruck. romantische Philosophie. Lingua romana. Wechselerhöhung und Erniedrigung" (1975, s. 493-494).
\end{abstract}

Yukarıdaki alıntı, “(d)ünya romantikleştirilmek zorundadır” diye başlar. Bu romantikleştirme işlemi; "basit olana yüce bir anlam, alışıldık olana bilinmeyenin heybetini, sonluya sonsuzun görünüşünü vererek" ve aynı şekilde “yüce, bilinmeyen, mistik, sonsuz olan'a” da tam tersi görünüş vererek gerçekleştirilecektir. Dünyanın romantikleştirilmek zorundalığının nedenini, "asli anlamını" yeniden keşfedebilmek şeklinde gerekçelendirir. Birbiriyle uzlaşmaz görünen antagonistik kavramları kasıtlı olarak iç içe geçiren bu "romantikleştirme" işlemi; yaşamı salt görünen, somut, kanıtlanabilir, deney(im)sel olana ve insanı da salt us'a ve bilince indirgeyen aydınlanmacı modernizmin hiyerarşik karşıtlıklarla ("basit/ yüce”, "sonlu/ sonsuz” vb.) işleyerek diğerini öteki-leş-tiren bakış açısına karşı adeta bir panzehir sunar. Kaiser, Novalis'in bu "tümüyle farklı unsurları birbiriyle ilişkilendiren," ${ }^{14}$ sanatı ve yazını yaşamla iç içe geçiren "romantikleştirme" operasyonun, Schlegel'in sanat ve bilimle sanat ve yaşam arasındaki sınırları aşan yazın programıyla örtüştüğünü vurgular (2010, s. 24-25).

Postmodernizmin sanat anlayışına gelince; özellikle 1960'lardan itibaren modernizmin hiyerarşik karşıtlıklarla işleyen kanonik ve seçkinci estetizmi başta olmak üzere, özgünlük (orjinalite) ülküsüne, türsel bütünlük anlayışına ve geleneksel karşıtlığına karşı çıkışıyla dikkat çeken bir yazın anlayışı olarak ortaya çıkmıştır. Amerikalı yazar John Barth (1930-) "The Literature of Exhaustion" (1967) adlı yazısında modernist yazının inşa ettiği gerçekçilik geleneğinin tükendiğini bildirerek modernizmi "tükeniş yazını" diye nitelendirir (Lucy, 2003, s. 155). Amerikalı yazın eleştirmeni Leslie Fiedler (19172003) de "Cross the Border-Close the Gap" (1968) adlı ünlü yazısında modernist yazının ölümünü bildirir. Nietzsche'nin ünlü söylemine gönderme yaparak "Eski Tanrı öldüğü gibi eski roman da ölmüştür artık” diyen Fiedler, yüksek yazının fildişi kulesini oluşturan kanonun dışına atılan (macera, western, bilim kurgu, romans, pornografi vb.) her bir türü kucaklayan; yazarı art, okuru ön plana çıaran; özgün değil, yeniden üretimsel olan; "eleştirmen ve izleyici arasındaki uçurumu” kapatarak geniş kitlelere yönelen postmodern sanatın doğumunu muştular (Fiedler, 1994, s. 14-39); (Kızıler, 2006,

\footnotetext{
Tarafımdan Türkçeye çevrilmiștir.

Tarafımdan Türkçeye çevrilmiştir.

Tarafımdan Türkçeye çevrilmiştir.
} 
s. 177 vd.). 70'lerden itibaren postmodernizm "farklı söylemleri/ türleri/ akımları/ metinleri çoğulcu yapısı içinde birbirine harmanlayarak bütünleştiren, metinlerarasıllğı yazınsal bir strateji haline getiren çokkatlı/ çokkodlu/ çoksesli diyalojik dokulu” (Emer Kızıler, 2019, s. 230) metinlerle yazın dünyasına bir kategori olarak yerleşir. Germanist Yıldız Ecevit postmodern sanatın öne çıkan özelliklerini şöyle özetliyor:

"Postmodern sanat da, çeşitli tarih kesitlerinden birden fazla sanat akımının, birden fazla biçemin birlikteliğinden oluşur; geleneksel akımlarda olduğu gibi, şemsiyesi altına aldığı yazarların her birinde yinelenen sanatsal ilkelere sahip bütüncül bir akım olmayıp, farklılıkların yan yana geldiği eklektik/ çoğulcu bir yapının adıdır. Yelpazesi öylesine geniş bir çoğulculuktur ki bu, geleneksel anlayışın, bir ürünün sanat düzlemine çıkabilmesi için koyduğu önkoşulları yok sayarak, sanatsal olan ile olmayan arasındaki sınırları bile ortadan kaldırır; kurmaca ya da değil, tüm yazı ürünlerini kanatları altına alır" (2004, s. 68).

Postmodernizmin "çoğulculuk" vizyonuyla romantizmin birlik özleminin olanca karşıtllğına (Welsch, 2002, s. 36) karşın, antagonistik unsurları eşit ve eşzamanlı bir birliktelik içinde yan yana getirmesi, sanatsal/ yazınsal ve sanatsal olmayan arasındaki sınırları kaldırması bakımından romantizmin Schlegel ve Novalis tarafından geliştirilen yazın programıyla örtüştüğü gözleniyor. Sarup’un "[...]: sanat ve gündelik yaşam arasındaki sınırların silinmesi; elit ve popüler kültür arasındaki sıradüzen ayrımının çökmesi; biçemsel eklektizm ve kodların karışımı" (1997, s. 190) şeklinde sıraladığı postmodernizmin başat özellikleri de her iki kavram arasındaki bu benzerliği berkitmektedir.

Romantiklerin bu her daim oluş halindeki "oluşumsal evrensel şiir” tasarımı postmodern yazınla birçok açıdan örtüşmektedir. Tıpkı romantizmde olduğu gibi, postmodernizmde de kural ve kuram karşıtllğı söz konusudur. Postmodern yazında da, romantik yazın programındaki gibi türler arasındaki sınırları belirsizleştirip türsel kanonu çözme (yapıbozuma uğratma) çabası vardır, hatta postmodernizmde bu, bizzat yazınsal bir strateji haline getirilmiştir. Öncü Fransız postyapısalcılardan Jacques Derrida'nın (1930-2004) batı felsefesinin temellerini sarsan yapıbozum/ yapısöküm (Dekonstruktion) stratejisi de ilginç biçimde Novalis'in bu "Romantikleştirme" operasyonunu anıştırır:

“[...] Derrida, yapıbozumun, ikili karşıtlıkları kendi değer hiyerarşileriyle açığa çıkaran, tersine çeviren ve söken, yani bir terimi öteki karşısında alçaltırken, her bir terimin öteki terimden hem farklılaştığını hem de onu ertelediğini (Derrida'nın "différance"ı bu hareketin her iki anlamını aynı anda yakalar) görmeyi başaramayan ve böylece, örneğin "iyi”nin anlamının, onun bağımlı karşıtı "kötü" ile iliş̧kisine bağlı olduğunu görmeyi başaramayan mantı̆̆ 1 savunulmaz kılan aynı araç olduğunu ileri sürer. Bu, yalnızca karşıt terimler arasında bir bulaşma derecesini ima etmekle kalmaz, "her biri” ötekinin bir tür izidir, [...]” (Sim, 2006, s. 406).

Bu çalışmada olduğu gibi Niall Lucy de "postmodemizmin, edebiyatı bir edebiyat meselesi olarak düşünen romantik bir gelenekten geldiği(ni)”, özellikle ilk dönem romantizminin yazınsal programıyla postmodernizm arasında bir bağlantı olduğunu savlar:

\footnotetext{
“1790’larda yaşayan Jena'daki Alman Romantikleri [...], edebi olanı, edebiyat kuramından ayrılmaz bir şey olarak tasarlamıştı: Edebiyat, kendini edebiyat, kuramı olarak sunuyordu bu modelde. [...]. Her şeyin bir metin olduğuna dair postmodern fikrin temelinde yatanın da bu soru olduğunu düşünüyorum. Postmodernizm için dışarı/ içeri ilişkileri sorunu, edebiyat sorusuyla sınırlı değildir, tüm kültür ve toplum alanına uzanır. Postmodemizme göre, bir zamanlar edebinin romantik uzamı olan yer, genel bir insani varoluş düzlemine dönüşür; [...]” (2003, s. 16).
}

Romantizmin "oluşumsal evrensel şiir” tasarımı ve “(d)ünyayı romantikleştirme” girişimi, postmodern yazının yüksek (kanonik) ve eğlencelik (trivial) unsurları eşzamanlı birliktelik içinde kullanmasıyla önemli ölçüde örtüşmektedir. Romantiklerin yaşamı da tüm yönleriyle poetize etme girişimi 
postmodernizmde her şeyin metin haline gelip "metnin dişında bir şey" in¹5 (Parla, 2000, s. 336) olmayışıyla en uç noktasına taşınmıştır. Taşdelen'e göre “(m)odernizmin yüce, asil, güzel, simetrik, rasyonel görkemli değerleri karşısında, postmodernizm popüler, gündelik, tüketilebilir, yüzeysel değerleri öne çıkarır, [...]. Sanatla hayat iç içe geçer.” (2007, s. 58).

"Şimdi çok farklı bir dönemde yaşıyoruz - apokaliptik, anti rasyonel, açıkça romantik -ve duyarlı" (1994, s. 15) diyen Fiedler, postmodernizmle romantizm arasındaki bağlantıya dikkat çeken ilk yazarlardan biridir: Yaşamı/ dünyayı "romantikleştirme" işlemini geliştiren Novalis'in "yaşamın bir düş olmadığı, ama olabileceği ve olması gerektiği” savının, "düşlerin bizzat üretilebileceğinin, televizyon ekranına yansıtılabileceğinin ya da azizlerin görülerinden geri kalmayan bir canlılık içinde lazer ışınlarıyla perdede yansitılabileceğinin öğrenildĭ̆̆” elektronik çağda postmodern bir yazınla gerçekleştirilebileceğini savunur: "Düş, vizyon ve esrime yeniden yazının amacı olmuştur” (s. 37). Alman yazar Hanns-Josef Ortheil da "sibernetik çağın yazını" olarak tanımladığı postmodernizmin "yaşamsal gerçekliğin göstergelerini yazınsal tasarım imi gibi” ${ }^{16}$ ele alarak estetik düzlemle yaşam kılgısı arasında bir bağ kurduğuna dikkat çekiyor (1994, s. 127).

Romantizmin eskiyi, geçmişi yadsımayıp onunla yeni arasında sentez kurma arzusu nostaljik bir özlemle geçmişe yönelen postmodernin geleneksel ve moderni iç içe geçirme eğilimiyle örtüşür (Ünal, 2011, s. 97). Modernizmin geçmişi ve geleneği yadsıyarak salt bugüne ve yeniye yönelmesi, "geçmişten kopmuş bir yeniyi kurmaya kalkışması” (Şaylan, 1999, s. 75) postmodernistlere göre sanatın kendi alanını kısıtlaması anlamına gelir. Bu nedenle postmodern sanat eklektiktir. Sanatta eklektisizmiyle; geçmişi/ eskiyi yadsımak yerine, modern’le/ yeniyle iç içe geçirerek bir arada kullanması bakımından bu iki duruş arasinda bir sentez kurar.

"Romantik sanatı müzik, resim ve edebiyat olarak ve bir bütün şeklinde anlamak gerekir" (Ünal, 2011, s. 107). Germanist Gürsel Aytaç da Friedrich Schlegel'in "edebiyatın bir "bütün” olduğu dile getiren ilk yazar olarak anıl(dığını)” (2003, s. 7-8) belirtir. Romantizmin, Schlegel ve Novalis tarafından geliştirilen yazın programının temelindeki bütünsellik düşüncesi; yani yazının sanatın diğer dallarıyla kaynaşarak - ki romantiklerin sıkça kullandığı sinestezi sanatı da bu anlayışın dışavurumudur - bir bütün oluşturduğu, sanatın yanı sıra bilimin diğer alanlarıyla iç içe geçtiği ve hatta bizatihi yaşamla örgensel bağları olduğu savı (Frenzel, 1987, s. 299) postmodernizmle örtüşür.

Kaiser'e göre, Schlegel'in "progressive Universalpoesie" tanımında geçen "ilerlemeci" ("progressiv") sıfatı, onun "tek tek metinlerin daima başka metinlere tepki niteliğinde ve başka metinlerle ilişkili" olarak ortaya çıktığını imler ki "bugünkü yazınbilimi bu nitelemeyi metinlerarasılık" diye adlandırır (Kaiser, 2010, s. 27). Bu romantik yazın tasarımı da postmodernistlerin, "(b)ütün edebiyatın metinlerarası()" (Eagleton, 2014, s. 149) olduğu savıyla örtüşmektedir.

Öte yandan kendi sanatsal üretimini ve metninde yarattığı yanılsamayı aşmak, varlığı daraltıp kalıplandıran gerçekliği, ruhun ve düşüncenin sonsuzluğuyla alt etmek amacıyla romantik ironi ("romantische Ironie") tekniğini sıkça kullanmasına benzer biçimde, postmodernizmde de ironi başat konumdadır. Dilin gerçekliğin temsilcisi değil, mimarı/ inşa edeni olduğu kavrayışından sonra içinde yaşadığımız elektronik (sanal) gerçeklik dünyasında, artık temsil ve yansıtmaya dayalı yazın anlayışı iptal olmuş ve ironi kaçınılmaz olarak öne geçmiştir. Türsel sınırları, kurmaca ve gerçek, sanat ve yaşam ayrımını yapıbozumuna uğratan, anti-mimetik yönelimiyle rotasını gerçek dünyayı yansıtmaktan, bizzat

"There is nothing ouitside the text [...]" (Derrida, 1997, s. 158).

Tarafımdan Türkçeye çevrilmiştir. 
kendi oluşumuna ve kurgulanışına çeviren, özgünlük ülküsü yerine metinlerarasılığı temel alan postmodernizmde üstkurmacanın, ironinin ve metinlerarasılığın başatlığı, onun romantizmle yakın ilişkisini ele veren en önemli unsurlardandır.

Postmodernistlerden önce romantikler "şiirin şiirini" ("Poesie der Poesie”), bir tür "aşkın şiir" ("Transzendentalpoesie") (Schlegel 2005, s. 105) üretmek arzusuyla, sanatsal yaratımı bizzat üretim sürecinin kendi iç dinamiklerine, kendi kuruluş olanaklarına ve koşullarına yöneltmiştir (Kaiser, 2010, s. 25). Postmodernizmde öne çıkan "(k)endisinin bilincinde olan, kendisine yönelik kurmaca (selfconscious/self-reflexive/self-refrential) sözcükleriyle tanımlanmaya çalışllan bu yeni kurgu eğilimi(nin)" yazınbiliminin terminolojisine "üstkurmaca (metafiction/surfiction) sözcügüule" aktarıldığını belirten Ecevit (2001, s. 99), kökeni Antikiteye dayanan bu tekniğin "(e)n çok da, tüm sınırları yok edip sonsuzluğun kanatlarının altında var olmayı amaçlayan romantikler()" tarafından kullanıldığına dikkat çekerek şunu ekler: "[...] edebiyat terimleri dizgesinde romantik ironi adıyla anılır (s. 124). Kaiser de gittikçe "artan öz-göndergesellik, dilsel olan her şeyin göstergesel ırası olduğu anlayışı, metinlerarası oyuna yönelik ilgi, [...] ironik tutumun başatlı̆̆” (2010, s. 120) gibi özelliklerin romantizmden sonra postmodernizmde yeniden ortaya çıktığını belirtir.

Toparlayacak olursak; romantizmin, yazının sanatın ve bilimin diğer alanlarıyla ve bizzat yaşamla bağlantıları olduğu, hepsinin bir bütün oluşturduğu savı, onun bir doğurgusu olarak gerçek-kurmaca ayrımını belirsizleştirme, türsel sınırları çökertme, metinlerarasılık, üstkurmaca, ironi vb. yazına mutlak anlamda özerklik tanınması vb. unsurların neredeyse hemen hepsi postmodernizmde de karşımıza çlkmaktadır. Sonuç olarak 19. yüzyll Romantiklerinin yazını her tür boyunduruk, dizge ve kalıptan kurtarma operasyonu, 20.yyın ikinci yarısında türler arası sınırları muğlaklaştıran, gerçek ve kurmaca ayrımı gibi yüksek (kanonik) ve eğlencelik (trivial) yazın ayrımını çökerten, geleneksel ve moderni iç içe sergileyen, antagonistik unsurları birbirine harmanlayan melez ve eklektik metinler üreten postmodernizmde bizzat yaşama geçirilmiştir. Romantizmin yazara ve yazına mutlak anlamda özgürlük tanınması istemi, Schlegel’in öne sürdüğü ana yasası bizzat kendisi olan "sonsuz" ve "özgür" bir yazın tasarımı olarak "romantik yazın, sanattan daha fazlası, adeta yazının bizatihi kendisi” olduğundan, bu bağlamda aslında "yazının tamamı romantiktir"17 (2005, s. 91) savı postmodernizmde büyük ölçüde gerçekleşmiştir, hatta öyle ki; bu öne çlkan başat özellikleri bağlamında postmodern metin evreni postromantiktir.

\section{Sonuç}

Çalışmada ortaya konulduğu gibi; düşünsel açıdan her iki kavram da öncelikli olarak Aydınlanmacı modernite eleştirisiyle ırasallaşır. Yazına mutlak anlamda özgürlük tanımaları, sanatla yaşam arasındaki keskin sınırları muğlaklaştırma girişimleri bakımından da sanata bakışları dikkat çekici ölçüde birbirleriyle örtüşür.

Her iki kavram arasında düşünsel ve yazınsal açıdan araştırılmaya değer bir benzerlik olduğu hipotezinden hareket eden bu makalede bu savı belgitlemek için; şu temel argümandan yararlanılmıştır: Erken Dönem Alman Romantizmin (Frühromantik) en önemli yazar ve kuramcılarından olan Friedrich W. Schlegel'in "evrensel şiir" ("Universalpoesie") kavramı ve Novalis'in dünyayı "romantikleştirme" (Romantisiren") tasarımı - ki bu iki tasarım aynı zamanda romantizmin yazınsal programını oluşturur -; kanonik/hiyerarşik/seçkinci modern yazının getirdiği ölçüt ve kategorileri yapıbozumuna uğratarak

17 Tarafımdan Türkçeye çevrilmiştir.

\footnotetext{
Adres | Address 
temellerinden sarsan 'anarşist ruhlu' postmodern yazınla romantizm arasındaki bağlantıları ortaya koymaktadır.

Bu çalışmada kabaca şu iki ana sonuca ulaşılmıştır:

1-Romantizm düşünsel, yaşamsal ve sanatsal açıdan modernizme yönelik olarak kayda değer ilk başkaldırı olup kendisinden yaklaşık iki yüzyıl sonra ortaya çıan postmodernizm, onun modernizme yönelttiği başkaldırıyı devralmıştır.

2-Romantizmin Schlegel ve Novalis tarafından geliştirilen yazın programı; antagonistik unsurları eşzamanlı bir birliktelik içinde yan yana getirmesi, yazınsal ve yazınsal/ sanatsal olmayan arasındaki sınırları muğlaklaştırarak yazınla yaşam arasındaki örgensel bağı vurgulaması postmodernizmin sanat anlayışılla büyük bir benzerlik gösterir.

Çalışmada gösterildiği gibi, 19. yüzyılda moderniteye yöneltilen ilk büyük eleştiri olarak tüm Kıta Avrupasına egemen olan Romantizm yazını yaşamla bütünleştirerek, her tür sınırlandırma ve sınıflandırmadan özgürleştirmeye çabalamış ve 20. Yüzyılın ikinci yarısından itibaren bu romantik istem adeta yeniden doğarak (postromantik) postmodernizm tarafından gerçekleştirilmiştir. Romantizmden iki yüzyıl kadar sonra ortaya çıkan postmodernizm, romantiklerin başlattığı modernite eleştirisini her anlamda en uç noktasına taşımış ve onların yazını mutlak anlamda özgürleştirme istemini bizzat kılgıya geçirmiştir; bu bağlamda postmodernizm, postromantiktir.

\section{Kaynakça}

Adorno, M. (2016). Negatif Diyalektik. Çev. Şeyda Öztürk. İstanbul: Metis.

Aytaç, G. (2003). Karşılaştırmah Edebiyat Bilimi. İstanbul: Say.

Birkök, C. M. (1998). "Modernizmden Postmodenizme: Yeni Problemler”. Yeni Türkiye Dergisi. C:4, s. 525-536.

Derrida, J. (1997). Of Grammatology. Trans. Gavatri Spivak, Baltimore: John Hopkins University Press.

Ecevit, Y. (2001). Türk Romanında Postmodernist Açllımlar. İstanbul: İletişim.

Emer Kızıler, F. (2019). "Patrick Süskind'in Amnesie In Litteris Adlı Metninin Postmodern Yazın Bağlamında Analizi”, International Journal of Economics, Politics, Humanities\& Social Sciences (IJEPHSS), Volume: 2, Issue: 4, s. 226-243.

Bumin T. (Yay. Haz.). Felsefe 20o2. Yayın No: TÜSİAD-T/ 2002/12-338, Cilt: 5, İstanbul: Lebib Yalkın.

Fiedler, L. (1994). "Überquert die Grenze. Schliesst den Graben”, in: Roman oder Leben, (Hg.) Uwe Wittstock, Leipzig: Reclam, S. 14-39.

Frenzel, H. A. und E. (1987). Daten der deutschen Dichtung. München: DTV.

Giddens, A. (1998). Modernliğin Sonuçları. Çev. Ersin Kuşdil. İstanbul: Ayrıntı.

Kaiser, G. (2010). Literarische Romantik. Göttingen: Vandenhoeck\&Ruprecht.

Kefeli, E. (2014). Batı Edebiyatında Akımlar. 2. Baskı. İstanbul: Dergâh.

Kizıler, F. (2006): Moderniteden Postmoderniteye Kavramsal Bir Yolculuk. Patrick Süskind'in Parfüm Adlı Romanında Postmodernist Açllımlar. Erzurum: Salkımsöğüt.

Lucy, N. (2003). Postmodern Edebiyat Kuramı. Çev. Aslıhan Aksoy. İstanbul: Ayrıntı.

Lyotard, J.F. (1984). Condition: A Report on Konowledge. Trans. Geoff Bennington a. Brian Massumi. Manchester University Press, Manchester. 
Lyotard J. F. (1986-1987). "Rules and Paradoxes or Svelte Appendix". Cultural Critique 5., s. 209. (İçinde: Featherstone, M. (1996). Postmodernizm ve Tüketim Kültürü. Çev. Mehmet Küçük. İstanbul: Ayrıntı).

Lyotard, J.F. (1998). “Postmoderne Dönüş”, Modernizmin Serüveni. (Yay. Haz.) Enis Batur. İstanbul: YKY, s. 20-21.

Novalis (1975): Dichtungen und Prosa, Leipzig: Philipp Reclam.

Ortheil, H. J. (1994). “Was ist postmoderne Literatur?”, in: Roman oder Leben, (Hg.) Uwe Wittstock (125-134). Leipzig: Reclam.

Parla, J. (2000). Don Kişot'tan Bugüne Roman. İstanbul: İletişim.

Paz, O. (1990). Öteki Ses. Çev. Mehmet Varlı. İstanbul: İnkılap.

Rothmann, K. (2003). Kleine Geschichte der deutschen Literatur. Stuttgart: Reclam.

Sarup, M. (1997). Post-Yapısalcıllk ve Postmodernizm. Çev. Baki Güçlü. Ankara: Ark.

Schlegel, F. (2005). “Athenäums”- Fragmente und andere Schriften. Stuttgart: Reclam, S. 76-143.

Schultz, K. (2006). Alman Kültür Tarihi. Çev. Yavuz Erkoç. Yay. Haz. Ahmet Sarı. Ankara: Orient.

Sim, S. (2006). Postmodern Düşüncenin Eleştirel Sözlüğü. Çev. Mukadder Erkan-Ali Utku. Ankara: Babil.

Şaylan, G. (1999). Postmodernizm. Ankara: İmge.

Taşdelen, V. (2007). “Postmodernizm Üzerine”. Hece Öykü, (Aralık-Ocak, 2007/ 2), s. 50-70.

Ünal, A. (2011). “Alman Romantizmi”. Selçuk Ünlü’ye Armağan. (93-130). Konya: Palet.

Vogelpohl, W. (2005). Alman Edebiyatı Tarihi. Çev. Yavuz Erkoç. Yay. Haz. Ahmet Sarı. Ankara: Orient.

Wackenroder,W.H.\&, Tieck, L. (2009). Herzensergiessungen eines kunstliebenden Klosterbruders. Ditzingen: Reclam.

Welsch, W. (2002). Unsere Postmoderne Moderne. Berlin: Akademie.

Wilpert, G. (1989): Sachwörterbuch der Literatur. Stuttgart: Alfred Kröner. 